\title{
Summary of the NACI Statement on Seasonal Influenza Vaccine for 2017-2018
}

\author{
W Vaudry ${ }^{1}$, R Stirling ${ }^{2}$ on behalf of the National Advisory Committee on Immunization (NACl)*
}

\begin{abstract}
Background: Influenza is a respiratory infection caused primarily by influenza A and B viruses. Vaccination is the most effective way to prevent influenza and its complications. The National Advisory Committee on Immunization (NACl) provides recommendations regarding seasonal influenza vaccines annually to the Public Health Agency of Canada (PHAC).
\end{abstract}

Objective: To summarize the $\mathrm{NACl}$ recommendations regarding the use of seasonal influenza vaccines for the 2017-2018 influenza season.

Methods: Annual influenza vaccine recommendations are developed by NACl's Influenza Working Group for consideration and approval by NACl, based on NACl's evidence-based process for developing recommendations. The recommendations include a consideration of the burden of influenza illness and the target populations for vaccination; efficacy and effectiveness, immunogenicity and safety of influenza vaccines; vaccine schedules; and other aspects of influenza immunization. These recommendations are published annually on the Agency's website in the NACl Advisory Committee Statement: Canadian Immunization Guide Chapter on Influenza and Statement on Seasonal Influenza Vaccine (the Statement).

Results: The annual statement has been updated for the 2017-2018 influenza season to incorporate recommendations for the use of live attenuated influenza vaccine (LAIV) that were contained in two addenda published after the 2016-2017 statement. These recommendations were 1) that egg-allergic individuals may be vaccinated against influenza using the low ovalbumin-containing LAIV licensed for use in Canada and 2) to continue to recommend the use of LAIV in children and adolescents 2-17 years of age, but to remove the preferential recommendation for its use.

Conclusion: $\mathrm{NACl}$ continues to recommend annual influenza vaccination for all individuals aged six months and older, with particular focus on people at high risk of influenza-related complications or hospitalization, people capable of transmitting influenza to those at high risk, and others as indicated.

\begin{abstract}
Affiliations
${ }^{1} \mathrm{NACl}$ Influenza Working Group Chair, University of Alberta, Edmonton, $A B$

${ }^{2}$ Centre for Immunization and Respiratory Infectious Diseases, Public Health Agency of Canada, Ottawa, ON
\end{abstract}

*Correspondence: naci-ccni@ phac-aspc.gc.ca

Suggested citation: Vaudry W, Stirling R on behalf of the National Advisory Committee on Immunization (NACl). Summary of the NACl Statement on Seasonal Influenza Vaccine for 2017-2018. Can Commun Dis Rep. 2017;43(5):96-103. https://doi.org/10.14745/ccdr.v43i05a03

\section{Introduction}

Influenza and pneumonia is ranked among the top 10 leading causes of death in Canada (1). Although the burden of influenza can vary from year to year, it is estimated that in a given year, there are an average of 12,200 hospitalizations related to influenza (2) and approximately 3,500 deaths attributable to influenza (3). The National Advisory Committee on Immunization ( $\mathrm{NACl}$ ) provides recommendations regarding seasonal influenza vaccines annually to the Public Health Agency of Canada (PHAC). The objective of this article is to summarize the $\mathrm{NACl}$ recommendations for the use of seasonal influenza vaccine for the 2017-2018 influenza season. Complete details can be found in the Statement on Seasonal Influenza Vaccine for 2017-2018 (4).

\section{Methods}

In the preparation of the 2017-2018 seasonal influenza vaccine recommendations, NACl's Influenza Working Group (IWG) identified and reviewed evidence regarding the administration of live attenuated influenza vaccine (LAIV) in egg-allergic individuals and vaccine effectiveness of LAIV and inactivated influenza vaccine (IIV) in children and adolescents 2-17 years of age. Following the review and analysis of this information, the IWG proposed updated recommendations for vaccine use to $\mathrm{NACl}$, based on NACl's evidence-based process for developing recommendations (5). NACl critically appraised the available evidence and approved the specific recommendations brought forward. Complete details of the literature review, rationale and relevant considerations for the updated recommendations can be found in the Addendum - LAIV Use in Egg Allergic Individuals (6), the Addendum - LAIV Use in Children and Adolescents (7), 
and the Canadian Immunization Guide Chapter on Influenza and Statement on Seasonal Influenza Vaccine for 2017-2018 (4).

For the review of LAIV use in egg-allergic individuals, data were obtained from three prospective cohort studies in the United Kingdom (UK) and Canada (8-10). Post-licensure safety data from the Canadian Adverse Events Following Immunization Surveillance System (CAEFISS) was analyzed to seek reports of adverse events in influenza vaccine recipients who describe a history of allergy to eggs.

Data on LAIV vaccine effectiveness in children and adolescents were obtained primarily from American studies using the test-negative design: the United States Influenza Vaccine Effectiveness Network (US Flu VE Network) (2010-2016) (11-14), the Influenza Clinical Investigation for Children (ICICLE) study (2013-2014 through 2015-2016 influenza seasons) (15-17) and the US Department of Defense (DoD) (2013-2014 and 2015-2016 influenza seasons) $(13,18)$. The American Household Influenza Vaccine Effectiveness (HIVE) study derived vaccine effectiveness data using an alternative household cohort design (2012-2013 and 2013-2014 seasons) $(19,20)$. Data on LAIV vaccine effectiveness from outside of the United States of America came from the Canadian Sentinel Practitioner Surveillance Network (SPSN) (2013-2014 and 2015-2016 seasons) $(21,22)$, Germany (2012-2013 season) (23), the UK sentinel surveillance network (2013-2014 through 2015-2016 seasons) (24-26), and Finland (2015-2016 season) (27). These studies used the test-negative design (21-26), with one prospective cohort study (27) and two cluster randomized trials $(28,29)$.

This article also presents information not provided in the published addenda or statement: figures summarizing the LAIV vaccine effectiveness data from the cited studies, by influenza season and influenza strain, as well as LAIV vaccine effectiveness data used to inform NACl's decision that were not publicly available when the Addendum was finalized, but have subsequently been published $(30,31)$.

\section{Results}

\section{New for the 2017-2018 influenza season}

There were two changes in $\mathrm{NACl}$ recommendations for the use of seasonal influenza vaccine for the 2017-2018 influenza season. Both changes related to updated recommendations on the use of LAIV.

\section{LAIV is safe for egg-allergic individuals}

All influenza vaccine products authorized for use in Canada are manufactured from influenza virus grown in chicken eggs, which may result in the vaccines containing trace amounts of residual egg protein. The formulation of LAIV licensed for use in Canada contains a low amount of residual ovalbumin (less than 0.24 $\mu \mathrm{g} /$ dose) (written communication from AstraZeneca), which is comparable to the amounts in IIVs available in Canada.

At the time of publication of the Canadian Immunization Guide Chapter on Influenza and Statement on Seasonal Influenza Vaccine for 2016-2017 (32), NACI did not recommend LAIV use in egg-allergic individuals due to a lack of data available to support this practice.
However, the safety of LAIV in egg-allergic individuals has now been studied in more than 1,100 children and adolescents (2-18 years of age) in the UK and Canada (8-10). After careful review of recently published studies, $\mathrm{NACl}$ concludes that egg-allergic individuals may be vaccinated against influenza using the low ovalbumin-containing LAIV licensed for use in Canada. The full dose of LAIV may be used without prior vaccine skin test and in any settings where vaccines are routinely administered. LAIV also appears to be well tolerated in individuals with a history of stable asthma or recurrent wheeze; however, it remains contraindicated for individuals with severe asthma (defined as currently on oral or high-dose inhaled glucocorticosteroids or active wheezing) or for those with medically attended wheezing in the seven days prior to immunization. The use of LAIV in egg-allergic individuals is a change from previous $\mathrm{NACl}$ statements.

Complete details of the literature review, rationale and relevant considerations for the updated recommendations can be found in the Addendum - LAIV Use in Egg Allergic Individuals (6) and the Canadian Immunization Guide Chapter on Influenza and Statement on Seasonal Influenza Vaccine for 2017-2018 (4).

\section{Current evidence supports the continued use of LAIV in children and adolescents 2-17 years of age but does not support its preferential use}

At the time of publication of the Canadian Immunization Guide Chapter on Influenza and Statement on Seasonal Influenza Vaccine for 2016-2017 (32), NACI recommended the preferential use of LAIV in children and adolescents 2-17 years of age who did not have contraindications to the vaccine. This recommendation was based upon randomized placebo controlled studies and post-marketing safety data that showed LAIV to be safe, efficacious and immunogenic in children and to provide better protection against influenza than trivalent IIV, especially in young children (less than six years of age), with weaker evidence of superior efficacy in older children (33).

The adjusted vaccine effectiveness estimates for LAIV and IIV against any influenza in children and adolescents (2-17 years of age) are summarized by study for the 2010-2011 through 2014-2015 (Appendix Figure 1) and 2015-2016 (Appendix Figure 2) influenza seasons. Summaries of adjusted vaccine effectiveness estimates by study and vaccine type are also provided for influenza $\mathrm{A}(\mathrm{H} 1 \mathrm{~N} 1)$ pdm09 (Appendix Figure 3), influenza $A(H 3 N 2)$ (Appendix Figure 4) and influenza $B$ (Appendix Figure 5) for these same influenza seasons (Note: In some influenza seasons, sample sizes were too small to derive vaccine effectiveness estimates for all influenza strains).

Based upon the US Flu VE Network data showing that LAIV provided no protective benefit during the influenza $A(H 1 N 1)$ dominant 2015-2016 influenza season and no evidence of effectiveness against the dominant circulating strains in the two prior influenza seasons (2013-2014 and 2014-2015), the American Advisory Committee on Immunization Practices (ACIP) recommended during its June 2016 meeting that LAIV should not be used during the 2016-2017 influenza season (34). LAIV continued to be recommended for use in children in the UK and Finland for the 2016-2017 season (35). Studies conducted in both of these countries and in Canada found a statistically significant overall protective effect of LAIV in children for 2015-2016, although sample sizes limited the precision of those estimates $(22,24,27)$. The United States Food and Drug Administration (US FDA) has also determined that specific regulatory action for LAIV was not necessary at the time, following a review of manufacturing and clinical data supporting licensure and the totality of evidence presented at the June 
2016 ACIP meeting, and continues to find that the benefits of quadrivalent LAIV outweigh any potential risks (36). Quadrivalent LAIV remains licensed for use in the US. The FDA's determination was made taking into account the limitations of observational studies in estimating vaccine effectiveness and the seasonal variability of influenza vaccine effectiveness.

After careful review of available studies from the last several influenza seasons, $\mathrm{NACl}$ concludes that the current evidence is consistent with LAIVs providing comparable protection against influenza to that afforded by IIV in various jurisdictions and has revised its recommendations on the use of influenza vaccine in children and adolescents 2-17 years of age:

1. In children and adolescents without contraindications to the vaccine, any of the following vaccines can be used: quadrivalent LAIV, quadrivalent inactivated influenza vaccine (QIV) or trivalent inactivated influenza vaccine (TIV).

2. The current evidence does not support a recommendation for the preferential use of LAIV in children and adolescents 2-17 years of age.

Given the burden of influenza B disease in children and the potential for lineage mismatch between the predominant circulating strain of influenza $B$ and the strain in a trivalent vaccine, $\mathrm{NACl}$ continues to recommend that a quadrivalent formulation of influenza vaccine be used in children and adolescents 2-17 years of age. If a quadrivalent vaccine is not available, TIV should be used.

The observational study data reviewed highlight the challenge in interpreting the vaccine effectiveness of LAIV and IIV when point estimates by influenza subtype are derived based on small sample sizes associated with wide confidence intervals. Therefore, in making its recommendations, $\mathrm{NACl}$ recognizes the need to continue to closely monitor the data on the vaccine effectiveness of LAIV by influenza subtype and the relative effectiveness of LAIV compared to IIV. NACI has also identified the need for further research to address current knowledge gaps:

3. $\mathrm{NACl}$ strongly encourages further multidisciplinary (e.g. epidemiology, immunology, virology) research to investigate the reasons for the discordant 2015-2016 vaccine effectiveness estimates between studies and explanations for poor LAIV effectiveness against $A(\mathrm{H} 1 \mathrm{~N} 1) p d m 09$ reported in some studies.

4. NACl strongly recommends that sufficient resources be provided to enhance influenza-related research and sentinel surveillance systems in Canada to improve the evaluation of influenza vaccine efficacy and effectiveness to provide the best possible evidence for Canadian influenza vaccination programs and recommendations.

Complete details of the literature review, rationale and relevant considerations for the updated recommendations can be found in the Addendum - LAIV Use in Children and Adolescents (7) and the Canadian Immunization Guide Chapter on Influenza and Statement on Seasonal Influenza Vaccine for 2017-2018 (4).

\section{Summary of $\mathrm{NACl}$ recommendations for the use of influenza vaccines for the 2017-2018 influenza season}

$\mathrm{NACl}$ continues to recommend influenza vaccination for all individuals aged six months and older who do not have contraindications to the vaccine, with particular focus on people at high risk of influenza-related complications or hospitalization, people capable of transmitting influenza to those at high risk of complications, and others as indicated in Table 1.

\section{Table 1: Groups for whom influenza vaccination is particularly recommended}

People at high risk of influenza-related complications or hospitalization

- All pregnant women ${ }^{1}$.

- Adults and children with the following chronic health conditions:

o cardiac or pulmonary disorders (including bronchopulmonary dysplasia, cystic fibrosis and asthma):

o diabetes mellitus and other metabolic diseases:

o cancer, immune compromising conditions (due to underlying disease, therapy or both);

o renal disease;

o anemia or hemoglobinopathy

o neurologic or neurodevelopment conditions ${ }^{2}$;

o morbid obesity (body mass index [BMI] of 40 years and over);

o children and adolescents (age 6 months to 18 years) undergoing treatment for long periods with acetylsalicylic acid, because of the potential increase of Reye's syndrome associated with influenza.

- $\quad$ People of any age who are residents of nursing homes and other chronic care facilities.

- People 65 years of age and older.

- All children 6 to 59 months of age.

- Indigenous peoples.
People capable of transmitting influenza to those at high risk

- Health care and other care providers in facilities and community settings who, through their activities, are capable of transmitting influenza to those at high risk of influenza complications.

- Household contacts (adults and children) of individuals at high risk of influenza-related complications (whether or not the individual at high risk has been immunized):

o household contacts of individuals at high risk, as listed in the section above:

o household contacts of infants under six months of age as these infants are at high risk of complications from influenza but cannot receive influenza vaccine;

o members of a household expecting a newborn during the influenza season.

- Those providing regular child care to children 59 months of age and under, whether in or out of the home.

- Those who provide services within closed or relatively closed settings to persons at high risk (e.g. crew on a ship).

Others

- People who provide essential community services.

- People in direct contact during culling operations with poultry infected with avian influenza.

The risk of influenza-related hospitalization increases with length of gestation (i.e. it is higher in the third than in the second trimester)

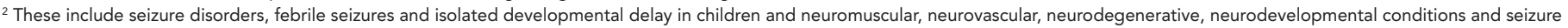
disorders in adults, but exclude migraines and neuropsychiatric conditions without neurological conditions 
Recommended influenza vaccine options by specific age and risk groups and by dosage and route of administration by age are summarized in Table 2 and Table 3, respectively.

Table 2: Choice of influenza vaccine for selected age and risk groups (for persons without a contraindication to the vaccine) ${ }^{1}$

\begin{tabular}{|c|c|c|}
\hline $\begin{array}{l}\text { Recipient } \\
\text { by age } \\
\text { group }\end{array}$ & $\begin{array}{c}\text { Vaccine types } \\
\text { available for } \\
\text { use }\end{array}$ & Comments \\
\hline $\begin{array}{l}\text { Children } \\
6-23 \text { months } \\
\text { of age }\end{array}$ & $\begin{array}{ll}\text { - } & \text { TIV } \\
\text { - } & \text { OIV } \\
\text { - ATIV }\end{array}$ & $\begin{array}{l}\text { TIV, OIV and ATIV are authorized for this } \\
\text { age group } \\
\text { NACI recommends that, given the } \\
\text { burden of influenza B disease, QIV should } \\
\text { be used. If OIV is not available, either } \\
\text { unadjuvanted or adjuvanted TIV should } \\
\text { be used }\end{array}$ \\
\hline $\begin{array}{l}\text { Children } \\
2-17 \text { years } \\
\text { of age }\end{array}$ & $\begin{array}{ll}\text { - } & \text { TIV } \\
\text { - } & \text { QIV } \\
- & \text { Quadrivalent } \\
& \text { LAIV }\end{array}$ & $\begin{array}{l}\text { In children without contraindications } \\
\text { to the vaccine, any of the following } \\
\text { vaccines can be used: LAIV, OIV or TIV } \\
\text { The current evidence does not support a } \\
\text { recommendation for the preferential use } \\
\text { of LAIV in children and adolescents } 2-17 \\
\text { years of age } \\
\text { Given the burden of influenza B } \\
\text { disease in children and the potential } \\
\text { for lineage mismatch between the } \\
\text { predominant circulating strain of } \\
\text { influenza B and the strain in a trivalent } \\
\text { vaccine, NACI continues to recommend } \\
\text { that a quadrivalent formulation of } \\
\text { influenza vaccine be used in children } \\
\text { and adolescents } 2-17 \text { years of age. If a } \\
\text { quadrivalent vaccine is not available, TIV } \\
\text { should be used. } \\
\text { LAIV is not recommended for children } \\
\text { with immune compromising conditions } \\
\text { LAIV, TIV or OIV can be used in children } \\
\text { with chronic health conditions and without } \\
\text { contraindications (see full statement for } \\
\text { more details) (4) }\end{array}$ \\
\hline $\begin{array}{l}\text { Adults } \\
18-59 \text { years } \\
\text { of age }\end{array}$ & $\begin{array}{ll}\text { - } & \text { TIV } \\
\bullet & \text { OIV } \\
\bullet & \text { Quadrivalent } \\
& \text { LAIV }\end{array}$ & $\begin{array}{l}\text { TIV and QIV are the recommended } \\
\text { products for adults with chronic health } \\
\text { conditions } \\
\text { TIV and QIV, instead of LAIV, are } \\
\text { recommended for health care workers } \\
\text { LAIV is not recommended for adults with } \\
\text { immune compromising conditions }\end{array}$ \\
\hline $\begin{array}{l}\text { Adults } \\
60-64 \text { years } \\
\text { of age }\end{array}$ & $\begin{array}{l}\text { - TIV } \\
\text { QIV }\end{array}$ & $\begin{array}{l}\text { TIV and QIV are authorized for use in this } \\
\text { age group }\end{array}$ \\
\hline $\begin{array}{l}\text { Adults } 65 \\
\text { years of age } \\
\text { and older }\end{array}$ & $\begin{array}{ll}\text { - } & \text { TIV } \\
\text { - } & \text { OIV } \\
\text { - } & \text { High-dose TIV }\end{array}$ & $\begin{array}{l}\text { Given the burden of Influenza A(H3N2) } \\
\text { disease and evidence of better efficacy } \\
\text { in this age group, it is expected } \\
\text { that high-dose TIV should provide } \\
\text { superior protection compared with the } \\
\text { standard-dose intramuscular vaccine for } \\
\text { older adults. }\end{array}$ \\
\hline $\begin{array}{l}\text { Pregnant } \\
\text { women }\end{array}$ & $\begin{array}{l}\text { - TIV } \\
\text { QIV }\end{array}$ & $\begin{array}{l}\text { LAIV is not recommended because of } \\
\text { the theoretical risk to the fetus from } \\
\text { administering a live virus vaccine }\end{array}$ \\
\hline
\end{tabular}

\section{Conclusion}

$\mathrm{NACl}$ continues to recommend annual influenza vaccination for all individuals aged six months and older (noting product-specific age indications and contraindications), with particular focus on people at high risk of influenza-related complications or hospitalization, including all pregnant women; people capable of transmitting influenza to those at high risk; and others as indicated. For the 2017-2018 influenza season, NACI has also updated LAIV use recommendations: 1) egg-allergic individuals may be vaccinated against influenza using the low ovalbumin-containing LAIV licensed for use in Canada, and 2) LAIV continues to be recommended for use in children and adolescents 2-17 years of age, but is no longer recommended preferentially.

Table 3: Recommended influenza vaccine dosage and route, by age, for the 2017-2018 influenza season

\begin{tabular}{|c|c|c|c|c|c|c|}
\hline $\begin{array}{c}\text { Age } \\
\text { group }\end{array}$ & $\begin{array}{l}\text { TIV without } \\
\text { adjuvant }^{1}\end{array}$ & $\begin{array}{l}\text { QIV without } \\
\text { adjuvant }^{2} \\
\text { Intramuscular }\end{array}$ & $\begin{array}{l}\text { TIV without } \\
\text { adjuvant, } \\
\text { high-dose } \\
\text { (Fluzone } \\
\text { High-Dose) } \\
\text { Intramuscular }\end{array}$ & $\begin{array}{c}\text { MF59- } \\
\text { adjuvanted } \\
\text { TIV } \\
\text { (Fluad }^{\text {Fluad }} \\
\text { Pediatric } \\
\text { Fluad }^{\oplus} \text { ) }\end{array}$ & $\begin{array}{c}\text { LAIV } \\
\text { (FluMist }^{\circledR} \\
\text { Quadrivalent) } \\
\text { Intranasal }\end{array}$ & $\begin{array}{l}\text { Number } \\
\text { of doses } \\
\text { required }\end{array}$ \\
\hline $\begin{array}{l}6-23 \\
\text { months }\end{array}$ & $0.5 \mathrm{~mL}^{3}$ & $0.5 \mathrm{~mL}^{3}$ & N/A & $0.25 \mathrm{~mL}$ & N/A & 1 or $2^{4}$ \\
\hline $\begin{array}{l}2-8 \\
\text { years }\end{array}$ & $0.5 \mathrm{~mL}$ & $0.5 \mathrm{~mL}$ & N/A & N/A & $\begin{array}{c}0.2 \mathrm{~mL}(0.1 \mathrm{~mL} \\
\text { per nostril) }\end{array}$ & 1 or $2^{4}$ \\
\hline $\begin{array}{l}9-17 \\
\text { years }\end{array}$ & $0.5 \mathrm{~mL}$ & $0.5 \mathrm{~mL}$ & N/A & N/A & $\begin{array}{c}0.2 \mathrm{~mL}(0.1 \mathrm{~mL} \\
\text { per nostril) }\end{array}$ & 1 \\
\hline $\begin{array}{l}18-59 \\
\text { years }\end{array}$ & $0.5 \mathrm{~mL}$ & $0.5 \mathrm{~mL}$ & N/A & N/A & $\begin{array}{c}0.2 \mathrm{~mL}(0.1 \mathrm{~mL} \\
\text { per nostril) }\end{array}$ & 1 \\
\hline $\begin{array}{l}60-64 \\
\text { years }\end{array}$ & $0.5 \mathrm{~mL}$ & $0.5 \mathrm{~mL}$ & N/A & N/A & N/A & 1 \\
\hline $\begin{array}{l}65 \\
\text { years } \\
\text { and } \\
\text { older }\end{array}$ & $0.5 \mathrm{~mL}$ & $0.5 \mathrm{~mL}$ & $0.5 \mathrm{~mL}$ & $0.5 \mathrm{~mL}$ & N/A & 1 \\
\hline
\end{tabular}

Abbreviations: LAIV, live attenuated influenza vaccine (quadrivalent formulation); N/A, not applicable; QIV, quadrivalent inactivated influenza vaccine; TIV, trivalent inactivated influenza vaccine

${ }^{1}$ Influvac ${ }^{\circledast} 18$ years and older, Fluviral ${ }^{\circledast} 6$ months and older, Agriflu ${ }^{\circledast} 6$ months and older, Vaxigrip ${ }^{\circledast}$ 6 months and older, Fluzone ${ }^{\circledR} 6$ months and older

${ }^{2}$ Flulaval ${ }^{\oplus}$ Tetra 6 months and older, and Fluzone ${ }^{\circledast}$ Quadrivalent 6 months and older

${ }^{3}$ This information differs from the product monograph. Published and unpublished evidence suggest moderate improvement in antibody response in infants, without an increase in reactogenicity, with the use of full vaccine doses $(0.5 \mathrm{~mL})$ for unadjuvanted inactivated influenza vaccines $(37,38)$. This moderate improvement in antibody response without an increase in reactogenicity is the basis for the full dose recommendation for unadjuvanted inactivated vaccine for all ages. For more information, refer to Statement on Seasonal Influenza Vaccine for 2011-2012 (39)

${ }^{4}$ Children 6 months to less than 9 years of age who have never received the seasonal influenza vaccine require two doses of influenza vaccine, with a minimum interval of four weeks between doses. Eligible children less than 9 years of age who have properly received one or more doses of seasonal influenza vaccine in the past should receive one dose per influenza vaccination season thereafter

\section{Authors' statement}

This statement was prepared by the Influenza Working Group: Vaudry W (Chair), Grohskopf L, Henry E, Kumar D, Langley J, Lavoie M, McElhaney J, McGeer A, Moore D, Vinh D, Warshawsky B, Xiong J

\section{Conflict of Interest}

None.

\section{Acknowledgements}

$\mathrm{NACl}$ acknowledges and appreciates the contribution of Christina Bancej, Gina Charos, Althea House, Vanessa Meikle, Robert Stirling and Linlu Zhao to the statement.

NACI members: Gemmill I (Chair), Quach C (Vice-Chair), Dayneka N, Deeks S, Henry B, Marchant-Short S, Salvadori M, Sicard N, Vaudry W, Vinh D, Warrington R 
Liaison representatives: Blake $\mathrm{J}$ (Society of Obstetricians and Gynaecologists of Canada), Brophy J (Canadian Association for Immunization Research and Evaluation), Cohn A (Centers for Disease Control and Prevention, United States), Emili J (College of Family Physicians of Canada), Lavoie M (Council of Chief Medical Officers of Health), Mah C (Canadian Public Health Association), Moore D (Canadian Paediatric Society), Pham-Huy A (Association of Medical Microbiology and Infectious Disease Canada), Sartison E (Canadian Immunization Committee)

Ex-officio representatives: Barnes K (National Defence and the Canadian Armed Forces), Charos G (Centre for Immunization and Respiratory Infectious Diseases [CIRID], Public Health
Agency of Canada [PHAC]), Coleman G (Biologics and Genetic Therapies Directorate, Health Canada [HC]), Gallivan J (Marketed Health Products Directorate, HC), Pennock J (CIRID, PHAC), Pless R (CIRID, PHAC), Wong T (First Nations and Inuit Health Branch, $\mathrm{HC}$ )

\section{Funding}

The work of $\mathrm{NACl}$ is supported by the Public Health Agency of Canada.

\section{Appendix}

Figure 1: Adjusted vaccine effectiveness estimates against any influenza by study and vaccine type for the 2010-2011 through 2014-2015 influenza seasons in children and adolescents 2-17 years of age ${ }^{1}$

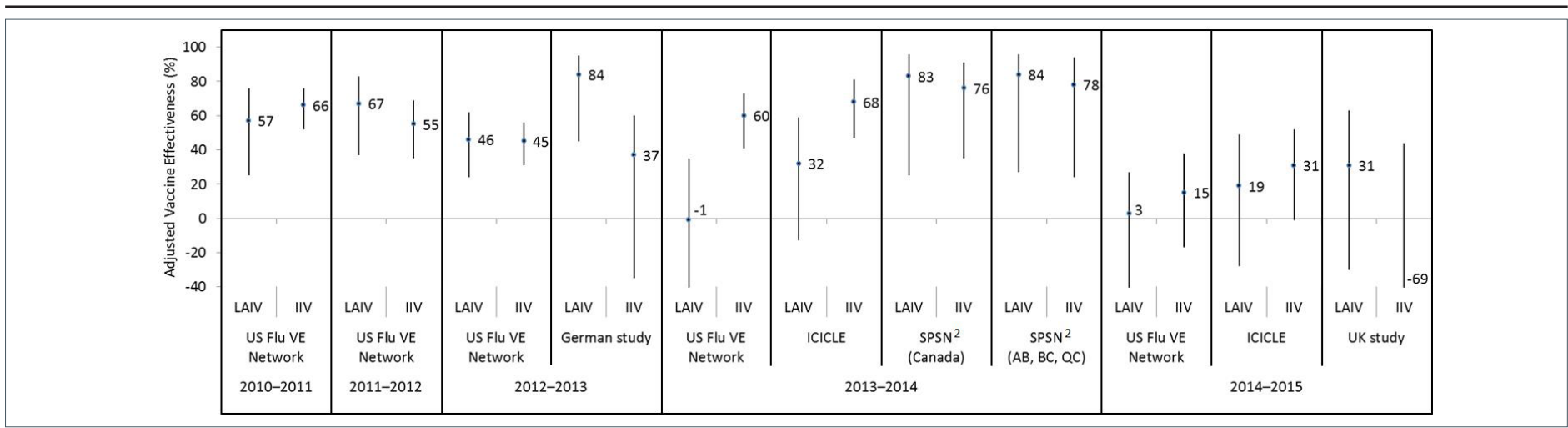

Abbreviations: ICICLE, Influenza Clinical Investigation for Children study; IIV, inactivated influenza vaccine; LAIV, live attenuated influenza vaccine; SPSN, Canadian Sentinel Practitioner Surveillance Network; US FLU VE Network, United States Influenza Vaccine Effectiveness Network; \%, percentage

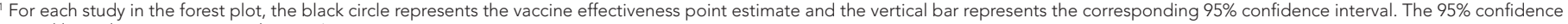
interval lower limits are truncated at $-40 \%$

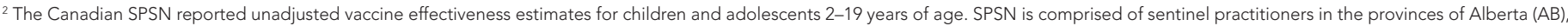
British Columbia (BC), Manitoba (MB), Ontario (ON) and Quebec (CC). LAIV was publicly funded in AB, BC and QC for the 2013-2014 influenza season

Figure 2: Adjusted vaccine effectiveness estimates against any influenza by study and vaccine type for the 2015-2016 influenza season in children and adolescents 2-17 years of age ${ }^{1}$

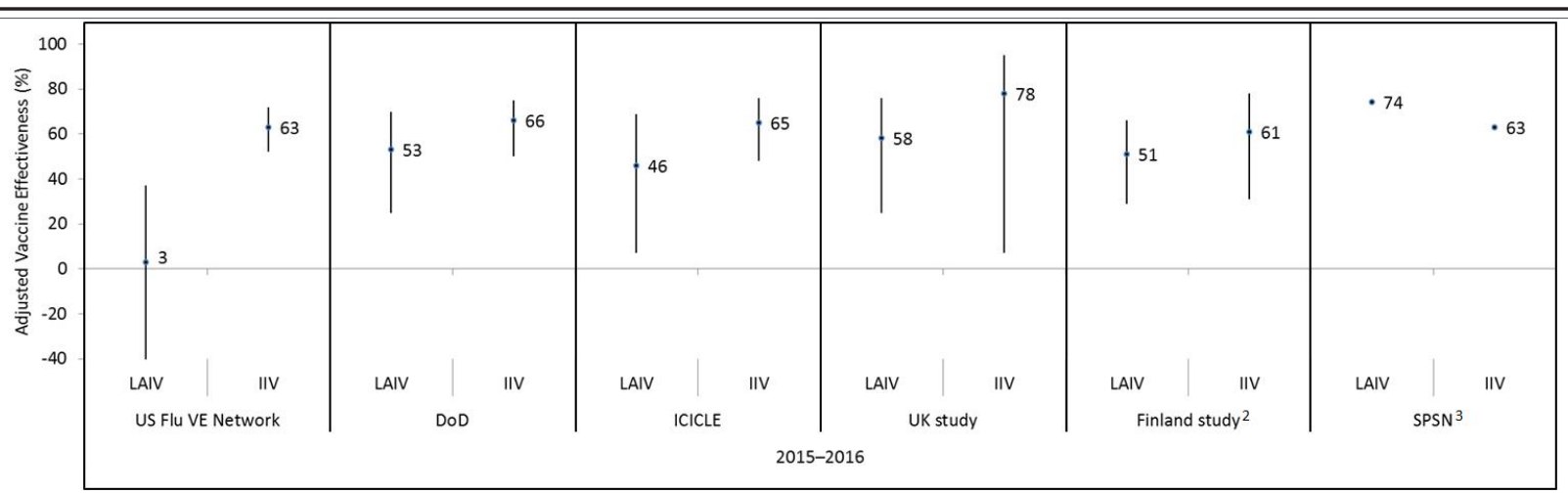

Abbreviations: DoD, United States Department of Defense; ICICLE, Influenza Clinical Investigation for Children study; IIV, inactivated influenza vaccine; LAIV, live attenuated influenza vaccine; SPSN, Canadian Sentinel Practitioner Surveillance Network; UK Study, United Kingdom Study; US FLU VE Network, United States Influenza Vaccine Effectiveness Network; \%, percentage

${ }^{1}$ For each study in the forest plot, the black circle represents the vaccine effectiveness point estimate and the vertical bar represents the corresponding $95 \%$ confidence interval. The $95 \%$ confidence interval lower limits are truncated at $-40 \%$

${ }^{2}$ The Finland national cohort study reported vaccine effectiveness in children two years of age

${ }^{3}$ The Canadian SPSN reported wide and overlapping 95\% confidence intervals (exact values not publicly available at time of writing) 


\section{Appendix continued}

Figure 3: Adjusted vaccine effectiveness estimates against influenza $A(\mathrm{H} 1 \mathrm{~N} 1) \mathrm{pdm} 09$ by influenza season, study and vaccine type in children and adolescents 2-17 years of age for $A(H 1 N 1)$ pdm09-dominant seasons since 20091

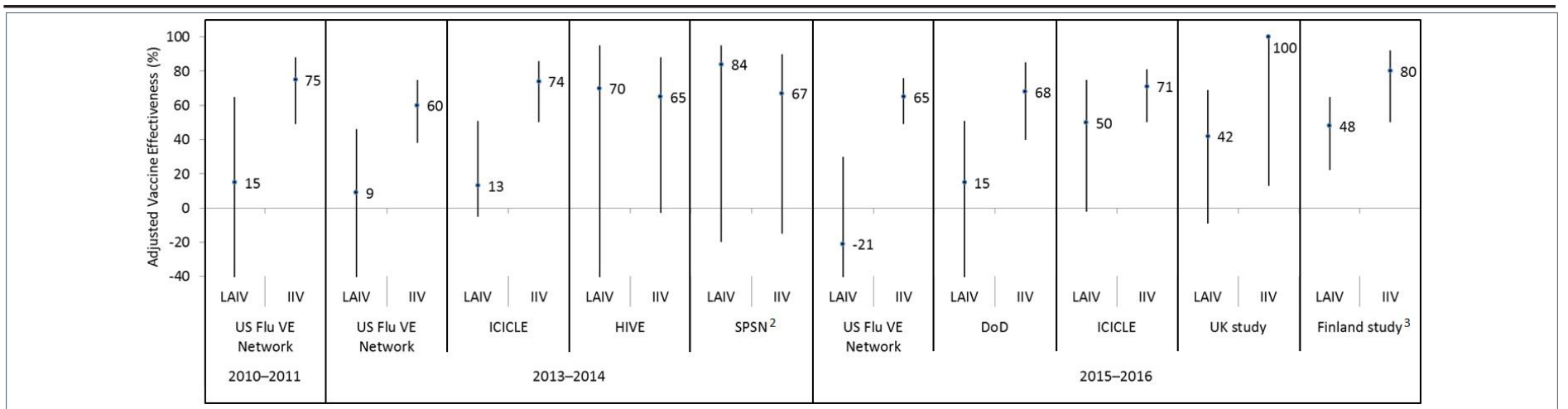

Abbreviations: DoD, United States Department of Defense; HIVE, American Household Influenza Vaccine Effectiveness; ICICLE, Influenza Clinical Investigation for Children study; IIV, inactivated

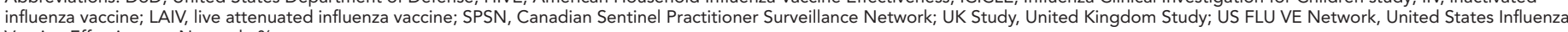
Vaccine Effectiveness Network; \%, percentage

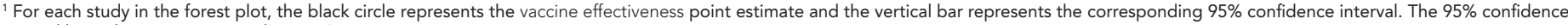
interval lower limits are truncated at $-40 \%$

2 The Canadian SPSN reported unadjusted vaccine effectiveness estimates

${ }^{3}$ The Finland national cohort study reported vaccine effectiveness against influenza $A$ in children two years of age

Figure 4: Adjusted vaccine effectiveness estimates against influenza $A(H 3 N 2)$ by influenza season, study and vaccine type in children and adolescents 2-17 years of age for $A(H 3 N 2)$-dominant seasons since 20091

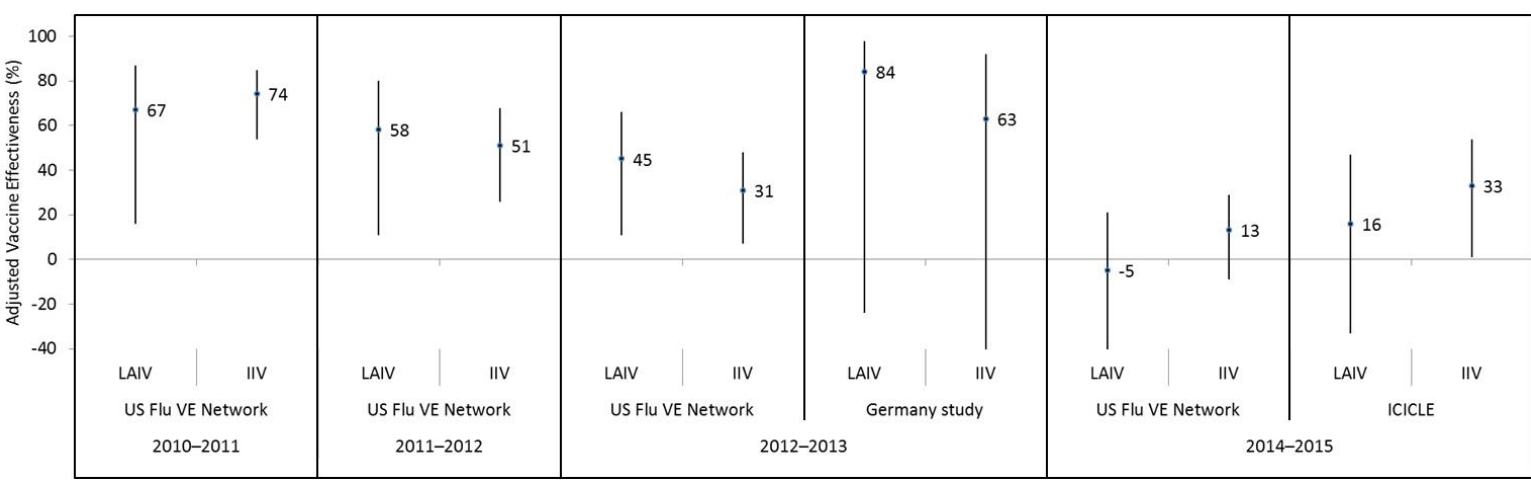

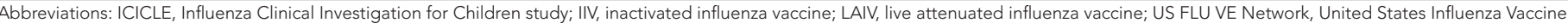

Effectiveness Network; \%, percentage
${ }^{1}$ For each study in the forest plot, the black circle represents the vaccine effectiveness point estimate and the vertical bar represents the corresponding $95 \%$ confidence interval. The $95 \%$ confidence interval lower limits are truncated at $-40 \%$

Figure 5: Adjusted vaccine effectiveness estimates against influenza B since 2009 by influenza season, study and vaccine type in children and adolescents $2-17$ years of age ${ }^{1}$

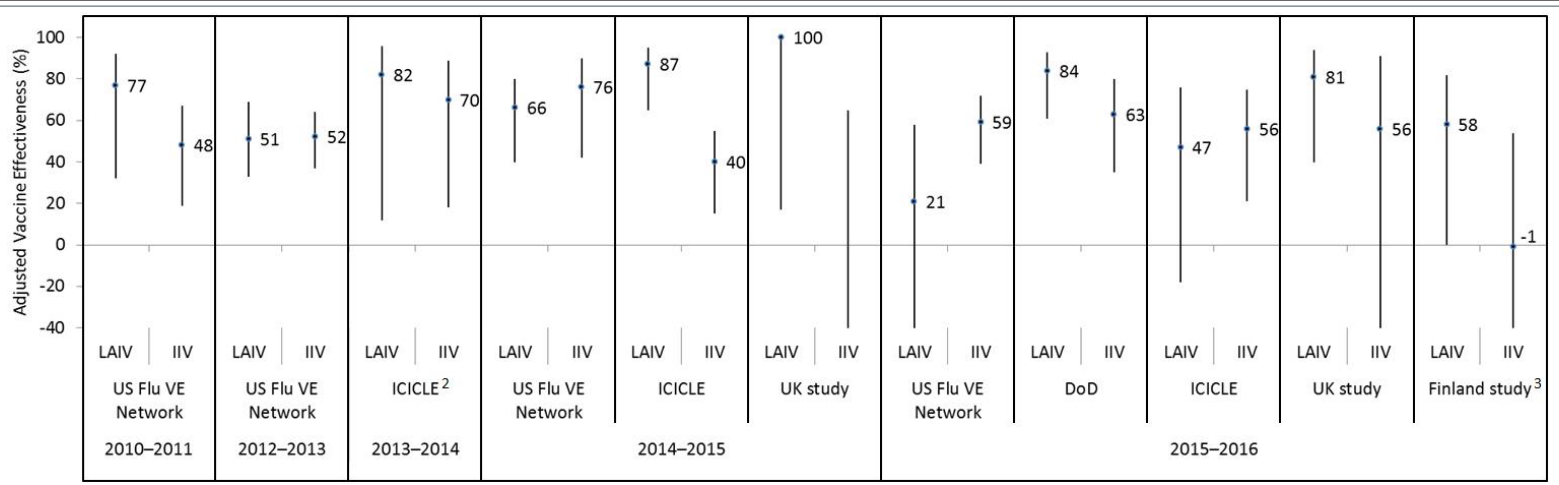

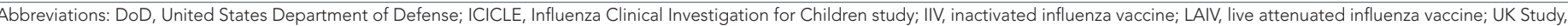
United Kingdom Study; US FLU VE Network, United States Influenza Vaccine Effectiveness Network; \%, percentage

' For each study in the forest plot, the black circle represents the vaccine effectiveness point estimate and the vertical bar represents the corresponding $95 \%$ confidence interval. The $95 \%$ confidence interval lower limits are truncated at $-40 \%$

${ }^{2}$ The ICICLE study reported vaccine effectiveness against influenza B/Yamagata for the 2013-2014 influenza season

${ }^{3}$ The Finland national cohort study reported vaccine effectiveness in children two years of age 


\section{References}

1. Statistics Canada. The 10 leading causes of death, 2011 [Internet]. Ottawa: Statistics Canada; 2014 [updated 2015 Nov 27; cited 2017 Feb 14]. Available from: http://www. statcan.gc.ca/pub/82-625-x/2014001/article/11896-eng.htm.

2. Schanzer DL, McGeer A, Morris K. Statistical estimates of respiratory admissions attributable to seasonal and pandemic influenza for Canada. Influenza Other Respir Viruses. 2013;7(5):799-808.

3. Schanzer DL, Sevenhuysen C, Winchester B, Mersereau T. Estimating influenza deaths in Canada, 1992-2009. PLoS One. 2013;8(11):e80481.

4. National Advisory Committee on Immunization (NACl). Canadian Immunization Guide Chapter on Influenza and Statement on Seasonal Influenza Vaccine for 2017-2018 [Internet]. Ottawa: PHAC; 2017 [updated 2017 May 2; cited 2017 May 2]. Available from: https://www.canada. ca/en/public-health/services/publications/healthy-living/ canadian-immunization-guide-statement-seasonal-influenzavaccine-2017-2018.html.

5. National Advisory Committee on Immunization (NACl). Evidence-based recommendations for immunization - Methods of the National Advisory Committee on Immunization. Can Commun Dis Rep. 2009;35:ACS-1. Available from : http://www.phac-aspc.gc.ca/publicat/ccdrrmtc/09vol35/acs-1/index-eng.php.

6. National Advisory Committee on Immunization (NACl). Addendum - LAIV use in egg allergic individuals [Internet]. Ottawa: PHAC; 2016 [updated 2016 Aug 30; cited 2017 Feb 14]. Available from: http://www.phac-aspc.gc.ca/naci-ccni/ flu-2016-grippe-addendum-eggs-oeufs-eng.php.

7. National Advisory Committee on Immunization (NACl). Addendum - LAIV use in children and adolescents [Internet]. Ottawa: PHAC; 2016 [updated 2016 Aug 30; cited 2017 Feb 14]. Available from: http://www.phac-aspc.gc.ca/naci-ccni/ flu-2016-grippe-addendum-children-enfants-eng.php.

8. Turner PJ, Southern J, Andrews NJ, et al. Safety of live attenuated influenza vaccine in atopic children with egg allergy. J Allergy Clin Immunol. 2015;136(2):376-81.

9. Turner PJ, Southern J, Andrews NJ, et al. Safety of live attenuated influenza vaccine in young people with egg allergy: multicenter prospective cohort study. BMJ. 2015;351:h6291.

10. Des Roches A, Samaan K, Graham F, et al. Safe vaccination of patients with egg allergy by using live attenuated influenza vaccine. J Allergy Clin Immunol Pract. 2015;3(1):138-9.

11. Chung JR, Flannery B, Thompson MG, et al. Seasonal effectiveness of live attenuated and inactivated influenza vaccine. Pediatrics. 2016;137(2):e20153279.

12. Flannery B, Clippard J. End-of-season influenza vaccine effectiveness estimates for the 2014-15 season: US Influenza Vaccine Effectiveness (Flu VE) Network. Presented to Advisory Committee on Immunization Practices, Atlanta. 2015.

13. Flannery B, Chung J. Influenza vaccine effectiveness, including LAIV vs IIV in children and adolescents, US Flu VE
Network, 2015-16. Presented to Advisory Committee on Immunization Practices, Atlanta. 2016.

14. Flannery B. LAIV vs IIV effectiveness: Summary of evidence since 2009. Presented to Advisory Committee on Immunization Practices, Atlanta. 2016.

15. Caspard H, Gaglani M, Clipper L, et al. Effectiveness of live attenuated influenza vaccine and inactivated influenza vaccine in children 2-17 years of age in 2013-2014 in the United States. Vaccine. 2016;34(1):77-82.

16. Ambrose C. 2015-16 US influenza vaccine effectiveness: Influenza Clinical Investigation for Children (ICICLE) Study. Presented to Advisory Committee on Immunization Practices, Atlanta. 2016.

17. Coelingh K. Update on live attenuated influenza vaccine (LAIV). Presented to National Advisory Committee on Immunization Influenza Working Group, Ottawa. 2015.

18. Cost A. Influenza vaccine effectiveness: Air Force children, 2013-2014 influenza season. Presented to Advisory Committee on Immunization Practices, Atlanta. 2014.

19. Ohmit SE, Petrie JG, Malosh RE, et al. Influenza vaccine effectiveness in households with children during the 20122013 season: assessments of prior vaccination and serologic susceptibility. J Infect Dis. 2015;211(10):1519-28.

20. Ohmit SE, Petrie JG, Malosh RE, et al. Substantial influenza vaccine effectiveness in households with children during the 2013-2014 influenza season, when 2009 pandemic influenza $A(H 1 N 1)$ virus predominated. J Infect Dis. 2016;213(8):122936.

21. Skowronski DM, Chambers C, Sabaiduc S, et al. Integrated sentinel surveillance linking genetic, antigenic, and epidemiologic monitoring of influenza vaccine-virus relatedness and effectiveness during the 2013-2014 influenza season. J Infect Dis. 2015;212(5):726-39.

22. Skowronski DM. Live attenuated influenza vaccine (LAIV) vs. inactivated influenza vaccine (IIV): summary of effectiveness evidence since 2009. Presented to National Advisory Committee on Immunization Influenza Working Group, Ottawa. 2016.

23. Helmeke C, Grafe L, Irmscher HM, et al. Effectiveness of the 2012/13 trivalent live and inactivated influenza vaccines in children and adolescents in Saxony-Anhalt, Germany: a test-negative case-control study. PLoS One. 2015;10(4):e0122910.

24. Public Health England. Influenza vaccine effectiveness in adults and children in primary care in the UK: provisional end-of-season results 2015-16 [Internet]. London: Public Health England; 2016 [updated 2016 Jun; cited 2017 Mar 9]. Available from: https://www.gov.uk/government/uploads/ system/uploads/attachment_data/file/530756/Influenza_ vaccine_effectiveness_in_primary_care_in_children.pdf.

25. Pebody RG, Green HK, Andrews N, et al. Uptake and impact of a new live attenuated influenza vaccine programme in England: early results of a pilot in primary schoolage children, 2013/14 influenza season. Euro Surveill. 2014;19(22). 
26. Pebody R, Warburton F, Andrews N, et al. Effectiveness of seasonal influenza vaccine in preventing laboratoryconfirmed influenza in primary care in the United Kingdom: 2014/15 end of season results. Euro Surveill. 2015;20(36).

27. Nohynek H. Seasonal childhood influenza vaccinations: Experiences from Finland. Presented at the Nordic Vaccine Meeting, Iceland. 2016.

28. Kwong JC, Pereira JA, Quach S, et al. Randomized evaluation of live attenuated vs. inactivated influenza vaccines in schools (RELATIVES) cluster randomized trial: pilot results from a household surveillance study to assess direct and indirect protection from influenza vaccination. Vaccine. 2015;33(38):4910-4915.

29. Loeb M, Russell ML, Manning $\vee$, et al. Live attenuated versus inactivated influenza vaccine in Hutterite children: a cluster randomized blinded trial. Ann Intern Med. 2016;165(9):617_ 24.

30. Pebody R, Warburton F, Ellis J, et al. Effectiveness of seasonal influenza vaccine for adults and children in preventing laboratory-confirmed influenza in primary care in the United Kingdom: 2015/16 end-of-season results. Euro Surveill. 2016;21(38).

31. Nohynek H, Baum U, Syrjänen R, et al. Effectiveness of the live attenuated and the inactivated influenza vaccine in two-year-olds-a nationwide cohort study Finland, influenza season 2015/16. Euro Surveill. 2016;21(38).

32. National Advisory Committee on Immunization (NACl). Canadian Immunization Guide Chapter on Influenza and Statement on Seasonal Influenza Vaccine for 2016-2017 [Internet]. Ottawa: PHAC; 2016 [updated 2016 Aug 30; cited 2017 Feb 14]. Available from: http://www.phac-aspc.gc.ca/ naci-ccni/assets/pdf/flu-2016-2017-grippe-eng.pdf.

33. National Advisory Committee on Immunization (NACl). Revised wording to the National Advisory Committee on Immunization recommendation for live attenuated influenza vaccine (LAIV) in healthy children and adolescents 2-17 years of age [Internet]. Ottawa: PHAC; 2013 [updated 2013 Nov 14; cited 2017 Feb 14]. Available from: http://www.phacaspc.gc.ca/publicat/ccdr-rmtc/13vol39/acs-dcc-4/rev-eng. php.

34. Centers for Disease Control and Prevention (CDC). ACIP votes down use of LAIV for 2016-2017 flu season [Internet]. Atlanta: CDC; 2016 [updated 2016 Jun 22; cited 2017 Mar 1]. Available from: http://www.cdc.gov/media/releases/2016/ s0622-laiv-flu.html.

35. Public Health England. Child flu vaccine plays important role in annual flu programme [Internet]. London: Public Health England; 2016 [updated 2016 Jun 23; cited 2017 Mar 1]. https://www.gov.uk/government/news/child-flu-vaccineplays-important-role-in-annual-flu-programme.

36. US Food and Drug Administration (FDA). FDA Information Regarding FluMist Quadrivalent Vaccine [Internet]. Silver Spring: US FDA; 2016 [updated 2016 Jun 27; cited 2017 Mar 1]. Available from: http://www.fda.gov/ BiologicsBloodVaccines/Vaccines/ApprovedProducts/ ucm508761.htm.

37. Langley JM, Vanderkooi OG, Garfield HA, et al. Immunogenicity and safety of 2 dose levels of a thimersolfree trivalent seasonal influenza vaccine in children aged 6-35 months: a randomized, controlled trial. J Pediatric Infect Dis Soc. $2012 ; 1(1): 55-63$

38. Skowronski DM, Hottes TS, Chong M, et al. Randomized controlled trial of dose response to influenza vaccine in children aged 6 to 23 months. Pediatrics. 2011;128(2):e27689.

39. National Advisory Committee on Immunization (NACl). Statement on Seasonal Influenza Vaccine for 2011-2012 [Internet]. Ottawa: PHAC; 2011 [updated 2011 Oct 14; cited 2017 Feb 14]. Available from: http://www.phac-aspc.gc.ca/ publicat/ccdr-rmtc/11vol37/acs-dcc-5/assets/pdf/acs-dcc-5eng.pdf. 